\section{Research Article}

(c) 2022 Al-Zoubi et al. This is an open access article licensed under the Creative Commons Attribution-NonCommercial 4.o International License (https://creativecommons.org/licenses/by-nc/4.o/)

\title{
Good Governance in Jordanian Universities and Its Relationship with the Ability to Solve Administrative Problems, from the Point of View of Faculty Members
}

\author{
Zohair Hussein Al-Zoubi \\ Associate Professor, Department of Foundations and Administration, \\ Faculty of Educational Science, The Hashemite University, \\ P.O. Box 330127, Zarqa 13133, Jordan

\section{Omar T. Bataineh} \\ Associate Professor, Department of Foundations and Administration, \\ Faculty of Educational Science, The Hashemite University, \\ P.O. Box 330127, Zarqa 13133, Jordan
}

\section{Lina Zakaria M. Qasem}

Lecturer A, Department of Foundations and Administration, Faculty of Educational Science, The Hashemite University, P.O. Box 330127, Zarqa 13133, Jordan

\section{Rana Mohammad Rawashdeh \\ Researcher, MA in Educational Administration, Jadara University, Irbid, Jordan}

DOI: https://doi.org/10.36941/jesr-2022-0o11

\section{Abstract}

The study aimed at revealing the application of good governance in Jordanian universities and its relationship to the ability to solve administrative problems from the point of view of faculty members. The sample of the study consisted of (330) members of the Faculties of Educational Sciences, and the study was conducted in the academic year 2020/2021. Using the descriptive research method, the researchers designed a questionnaire as a study tool and verified its validity and stability. The findings showed that good governance in Jordanian universities was at a high level, with the absence of statistically significant differences in good government by gender or years of experience. The findings also showed a high level of ability to solve administrative problems by the heads of academic departments in the faculties of educational sciences, with no statistically significant differences in the ability to solve administrative problems by gender or years of experience. There was a positive relationship between the degree of good governance and the ability to solve administrative problems.

Keywords: Good governance, administrative problems, faculty members, Jordanian universities 


\section{Introduction}

Universities encourage informed leaders who interact with changes in a scientific way, influence employees and reshape their behavior to the benefit of the institution; such leaders engage faculty and departmental members in good decision making which lead to the achievement of their objectives (Ruilly, 2018).

The importance of good governance has emerged in many developed and emerging organizations over recent decades, particularly in the wake of economic collapse and financial crises in a number of East Asian, Latin American countries and Russia in the 1990s (Solomon, 2004).

This diversity enriches the concept of governance; whose purpose is to develop the performance of the institution in order to achieve the objectives set; implementation of the principles of governance is essential to the successful performance of institutions. The governance of educational institutions is especially important, preparing and developing the workforce and human resources that run these institutions (Dhawi, 2011).

Al-Farra (2013) noted that the concept of university governance is the good practice of university administrative authorities; the decision-making process follows the rules, standards and discipline that determine the administration of the institution on the one hand, and satisfy the stakeholders or parties associated with the institution on the other. Al-Arini (2014) defined governance as being able to control all administrative processes in a scientific and rational way and to reform negative practices in institutions in general. It was similarly defined by Hattala and Salama (2017) as the means by which negative surprises are avoided; the relationship is regulated in the system and the completion time is determined by the clarity and credibility of decision making, as governance is based on the rules of fairness and justice. It is a comprehensive system that includes measures of good administration and indicators of the existence of control methods that prevent a negative impact on the activity of the institution.

Governance aims to achieve harmony and justice in all administrative processes within the institution in order to protecting the material and moral rights of individuals and provide accurately and quickly the necessary information on the activities of the institution. This increases confidence in the institution, in addition to ensuring that it has a good organizational administrative structure. At the same time, the development of procedural policies identifies the institution's powers and functions, as well as meeting its social responsibilities (Hanini, 2004).

The objectives of governance in university institutions can also be defined as follows: improving the performance of the educational institution, avoiding any risks or conflicts that hinder the quality of performance (Al-Shafei, 2009). It is also defined as improving administrative and educational practices, achieving justice, integrity and transparency in all the institution's dealings, promoting accountability, and creating a good administrative structure through which the objectives are achieved (Al-Mallahi, 2011).Moreover, it is defined as providing the right of accountability to all beneficiaries and those concerned with the existence of the university, through regulations and laws that guide the administration in order to ensure democracy and justice for all parties concerned. Governance also protects the rights of stakeholders, including beneficiaries of the educational institution's services, whether they are faculty members, students, employees or the community (AlQaisi, 2017).

Nasser al-Din (2012) notes that there are three principles of governance. First, Transparency involves designing and applying systems, mechanisms, policies and legislation. It also provides clarity on the internal workings of the university, with the easy flow of accurate and objective information and its ease of use and effective application by university staff. Second, Participation involves the academic and administrative bodies, students and society, to participate in policy making, and to develop the rules of action in various areas of university life. Third, Accountability means enabling relevant individuals inside and outside the university to monitor its work without disrupting it or abusing others.

When institutional governance is implemented through an appropriate methodology and 
codified procedures, corresponding distinctive characteristics emerge. Effendi (2004) describes these characteristics of institutional governance in educational institutions as follows:

- Disclosure and transparency: the flow and clarity of information to all those involved, in a timely manner.

- Active participation: allowing all relevant parties to participate in decisions, evaluation and development of plans and policies.

- Oversight and responsibility: implementing a mechanism that promotes oversight, responsibility and commitment to the rights of all relevant parties.

- Justice and integrity: applying laws and regulations and treating all parties on a fair basis without discrimination.

- Efficiency and effectiveness: translating the vision and mission, making decisions and investing resources to achieve goals with minimal effort and cost.

Universities worldwide, including those in Jordan, seek international rankings of their performance; to achieve excellence in performance, they must apply good governance (Dahshan, 2018).

In daily life, we meet many problems that must be solved by taking appropriate decisions and actions; these problems occur in many situations, including those at work, school, home and the society we live in, and we must confront and solve them if we are to have stable, reassuring lives. The activity of solving problems involves the mental processes to which the individual is exposed as he seeks to reach a goal, requiring the use of certain strategies to solve the problem according to a specific course and to implement it within specific steps (Zaghloul, 2003).

Beni Jaber et al. (2002) point out the differing views of researchers in their approach to the ability to solve problems: some focus on the cognitive aspect and mental processes, others on the behavioral aspect. A third group combines the mental and behavioral aspects; the cognitive processes in solving the problem appear in the form of the behavior and performance of the individual.

Hilal (2003) defines a problem as a state of tension and dissatisfaction as a result of some difficulties in setting or reaching goals; it is clearly manifested when an individual is unable to obtain the expected results from multiple actions and activities. Al-Adl and Abdul Wahab (2003) states that the ability to solve problems is: "The ability to derive results from given introductions, a kind of achievement provided by the individual from known facts and information to reach the unknown facts and information that he wishes to discover, by understanding the causes and factors that overlap in the problems he solves".

The ability to solve problems is defined as a set of steps and events in which man uses principles and relationships to reach the desired goal and purpose. Hammadat (2007) noted that a problem contains an obstacle between one's purpose and the specific goal to be achieved. Abu Nasser (2008) agreed that it as an obstacle to achieving goals, or a gap between the status quo and the hoped-for situation.

Aqelan (2011) explains that administrative problems are situations which hinder the achievement of the educational objectives and which need to be examined in order to understand their causes in preparation for treatment and resolution. Ahmed (2011) defines problem solving as a set of processes carried out by the individual using the information and knowledge he has already learned, and the skills he has acquired in overcoming a particular situation in a modern and unfamiliar way, by controlling it in order to find an appropriate solution. Al-Sudairi (2015) adds that the ability to solve problems is one of the most complex and important forms of human behavior; the problem is a difficult situation, or an obstacle preventing the individual from achieving a specific goal. Working in a state of cognitive imbalance, the individual therefore relies on his knowledge to face this situation and overcome it in order to reach the appropriate solution.

Anbaar (2015) noted that a problem is a situation that a person faces when he wants to know something and does not know exactly what to do in order to achieve it. The concept of administrative problems is a set of difficulties associated with administrative work, within the educational institution or other private or government institutions, and is linked to the planning, organization, 
communication, decision making, follow-up, guidance and evaluation processes.

The ability to solve problems is a mental process in which the individual uses his or her mental abilities to move from the unsatisfactory situation to the situation in which the problem is solved, that is the goal is reached. The method of solving the problem places the individual in a real position in which his mind works in order to reach a state of cognitive balance, the state of motivation that the individual seeks to achieve, until a solution, answer or discovery is found (Groan, 2007).

The problems faced by administrators vary according to their nature; Al-Harbi (2008) refers to some of following types:

- The problem with only one solution: the one-solution problem is not a problem at all, as there are no alternatives and therefore there is no choice between alternatives.

- The problem with unexpected solutions: that is, the solution to the problem lies in front of the decision maker.

- The malicious problem: a problem that can only be resolved safely after it has been implemented.

Solving any problem requires a number of skills in the leader of the institution, whether educational or non-educational. These skills include the following:

Communication skills: mastery of the arts of dialogue, listening, criticism and encouragement, mastery of the language of the eye, hand and body in communicating with others, keenness to listen to employees and build good relations with them, follow an open-door policy, and encouraging employees to express their opinions and suggestions with confidence, to facilitate the passage of information and instructions issued by the institution (Samara, 2007).

- Technical skills: the ability to organize, the ability to make rational decisions, find solutions and be creative in facing problems, to overcome obstacles, choose the right decision from among the available alternatives, and the ability to analyze data (Hamouda, 2005).

- Intellectual skills: creative thinking, a holistic view of things, the development of plans and strategies, prioritization, outlook on the future, predicting and solving problems before they occur, the optimal use of information to serve thinking, the full clarity of the vision and mission of the institution, the high, renewed and diverse culture that sharpens the mind and thought, and the possession of a holistic mind that looks at things from all angles, and an indepth view of the future and its challenges (Higgins, 2001).

There are steps in solving problems, as some problems present the educational leader with great challenges, and require a lot of thinking and research. Taking overlapping, integrated and interlocking steps in order to reach an optimal solution and a rational decision involves the following:

- Feeling the problem: this is the first and most important step; a clear and specific understanding of the problem is one of the basic skills of an effective educational leader, who is familiar with discovering underlying problems that have not yet surfaced. The problem is clearly defined and formulated: this is intended to identify the problem and describe its nature, elements, boundaries, scope and size. To formulate the problem means expressing it in a short reporting sentence or putting it in the form of a question that requires the search for an answer (Abedin, 2001).

- Problem analysis: this step requires the educational leader to classify the problem, collect data related to the problem and analyze and interpret the data in order to identify the causes of the problem. Looking for a solution and proposing possible alternatives: after the educational leader gathers information, ideas and underlying causes, he tries to propose a number of appropriate solutions and alternatives to address the problem and overcome it, relying on employing creative thinking and innovation, and the more solutions and alternatives the leader has, the better his chance to find an effective solution (Hariri, 2008).

- Evaluating solutions or alternatives: when the educational leader has a range of alternatives or possible solutions to the problem, he must evaluate them separately and compare their possible outcomes, so he needs to balance the arguments in favor of the alternative with the opposition to it. It excludes solutions or alternatives that do not take into account the 
constraints imposed and makes sure that the alternative or solution is realistic. Finally, he examines the risks associated with the best solution (Abu Ayed, 2006).

- Choosing the appropriate solution to the problem: the educational leader cannot apply all the solutions and alternatives to solve the problem because of the lack of time or the necessary means, so it is necessary to make a rational decision to choose the reasonable and applicable alternative to solve the problem in the light of the material and human potential available in the institution, to save time and effort, and implementing and evaluating the chosen solution. This step requires a practical application of the solution and the leader's experience in the reality of the problem, with notes on the findings. The educational leader can try a number of other solutions, and record his observations about the changes that occur in the desired direction, continuing until the desired solution is reached. We note here that the process of evaluation keeps pace with the process of testing solutions or hypotheses, coinciding with and tracking them (Hammadat, 2007).

A number of researchers have conducted studies on good governance, including Mortensen (2009), who found that the governance model in higher education is an integral part of America's high-policy situation. Wang (2010) also conducted a study that found that the application of governance with its principles (transparency, participation, accountability, coexistence of monitoring mechanisms and liberal practices) demonstrated creativity, innovation and the ability to promote it in the university and the state.

As Mok (2010) showed, senior university administrators were given the freedom to manage their universities; most academics felt no significant difference after the introduction of governance reforms. According to Mohammed (2011), there were several requirements, most notably spreading the culture of governance, considering academic freedom and accountability of universities as one of the most important criteria in university life, and amending laws and regulations governing universities and eliminating corruption in university life.

Dusu and Mungia (2011) found systemic problems in the organization and performance of university life due to failure to establish accountability systems at the university level. The result of Nasser al-Din's study (2012) showed that the reality of the application of governance was high, and there were differences attributable to years of experience. Al-Arini (2014) showed that the reality of application at Imam Mohammed University was achieved to a medium degree, with differences in the reality of the application of governance due to the differences in qualification, years of experience and current employment. Abu Debeil (2015) showed that the application of good governance in the administration of village education in Saudi Arabia was at an average level.

Muslim (2016) found that the level of governance principles was high. Al-Dahdar (2017) found that there were no standards for university governance and that universities applied the principles of governance to a medium degree. Al-Hamidi (2017) showed that the overall application of good governance at Taif University was medium, and that the constraints on the degree of implementation of good governance were significant. There were no differences in applying governance according to the variable specializations, academic rank or years of experience.

With regard to studies on the ability to solve administrative problems, the most important of Glimps' (1999) research was the impact of administrative cooperation and information gathering on increasing effectiveness in decision making. There were differences in favour of males in the extent to which administrative cooperation is used in decision making and problem solving. Abu Odeh (2004) found statistically significant differences between the averages of principals' estimates of the problems they face, and the average estimates of teachers under their administration. It also showed that there were statistically significant differences between the averages of secondary school estimates by gender, as well as differences with principals with less than five years' experience.

Similarly, there were no statistically significant differences between the averages of secondary school principals' estimates of the problems they faces, by their scientific or educational qualifications. Ruweished (2004) showed a number of administrative problems facing faculty members at teachers' colleges at significantly different levels, medium and low. There were also 
statistically significant differences by gender, in favor of females.

Obeidat (2004) found administrative problems in all aspects of the study to a neutral degree, with the element of organization in the last place, and the scientific qualifications in favor of males, in addition to age and experience. Al-Lahwani (2007) found differences in the areas of problems faced by UNRWA school administrators attributable to job title, and in the area of problems related to the curriculum, teachers, and in favour of the principals over the teachers. There were also differences in the problems facing school principals by years of experience.

Abu Aisha (2007) found statistically significant differences in the degree of educational planning problems in the fields of teachers and students between males and females, in favor of male principals, but lack of significant differences attributable to gender, scientific qualification, university specialization or number of years of experience. Nazzal (2009) showed that the degree of problem solving from the point of view of the principals of public secondary schools themselves was very high.

A statistically positive correlation was found between educational decisions and the ability to solve problems among the principals of public secondary schools in the governorates of the northern West Bank, corresponding to scientific qualifications and years of experience. Al-Obeid (2019) found that the level of administrative problem solving among principals was high, with a positive correlation between the patterns of transformational leadership and the level of problem solving; however, there were no statistically significant differences attributable to gender, scientific qualification or years of experience.

\section{$1.1 \quad$ Research Problem}

Based on the above review of previous scholarship on the principles of good governance, a set of legislation and policies was developed for public and private institutions to achieve objectives ethically, honestly and transparently through continuous evaluation and accountability, to ensure effective performance and the provision of services fairly and equally to all members of society. The firmer the application of the principles of governance, the more this is reflected in the ability of employees to solve administrative problems. This means the ability to derive results from the introductions given, which is the type of performance and achievement in which humans progress from known facts to reach unknown facts and discover through understanding the causes and overlapping factors of the problems. This study therefore seeks to answer the following questions, in relation to the Faculties of Educational Sciences in Jordanian universities:

1. How well do the heads of departments apply the principles of good governance?

2. Are there statistically significant differences at the level of significance $(\alpha=0.05)$ in the good governance of the heads of departments attributable to gender and years of experience, from the point of view of teachers?

3. What is the level of ability to solve administrative problems among the heads of academic departments from the point of view of the faculty members?

4. Are there statistically significant differences at the level of indication $(\alpha=0.05)$ in the level of ability to solve administrative problems among the heads of academic departments by gender or years of experience, from the point of view of faculty members?

5. Is there a relationship between the degree of application of the principles of good governance and the level of ability to solve administrative problems among the heads of academic departments, from the point of view of the faculty members?

\subsection{Research Method}

The researchers used the descriptive correlation approach to achieve the objectives of the study because it is commensurate with the nature of the subject. 


\subsection{Population}

The study community comprises all members in the Faculties of Educational Sciences in Jordanian universities $(1,430)$, according to statistics from the Ministry of Higher Education and Scientific Research for the academic year 2020/2021 (Statistics of the Ministry of Higher Education and Scientific Research, 2020). One public and one private university were selected from each of the three regions of the Hashemite Kingdom of Jordan: Yarmouk University and the University of Jadara from the Northern Region; the University of Jordan and the University of Zarqa from the Central Region; and Hussein Bin Talal University and the University of Isra from the Southern Region.

\section{Study Methodology and Procedures}

\subsection{Sample}

The sample of the study consisted of 330 faculty members, approximately $23 \%$ of the original community, from six Jordanian universities. The demographic variables of the sample are shown in Table 1.

Table 1: Distribution of the study sample according to the study variables

\begin{tabular}{|l|l|c|c|}
\hline \multicolumn{1}{|c|}{ variables } & \multicolumn{1}{|c|}{ category } & sample & percentage \\
\hline \multirow{2}{*}{ Gender } & Male & $\mathbf{2 2 0}$ & $67 \%$ \\
\cline { 2 - 4 } & Female & 110 & $33 \%$ \\
\hline \multirow{3}{*}{ Years of experience } & Less than 10 years & 107 & $32 \%$ \\
\cline { 2 - 4 } & $10-20$ years & 125 & $38 \%$ \\
\cline { 2 - 4 } & More than 20 years & 98 & $30 \%$ \\
\hline Total & 330 & $100 \%$ \\
\hline
\end{tabular}

\subsection{Research Methodology}

To achieve the goal of the study, the researchers used a questionnaire to identify the degree of good governance and the level of ability of heads of departments to solve administrative problems. The first section was based on the standards related to the application of the principles of good governance established in previous studies: the scales of Abu Debel (2006), Hamidi (2015), Dahshan (2018), Guanma (2018), Eid (2017), Sau'b (2020), Sarhan and Zaa'a (2018) and Ruilly (2018). The second section of the questionnaire, on standards related to the ability to solve administrative problems, was also based on existing scales: Abdul Wahab (2003), Aqeban (2011), Saliha (2011), Sudiri (2015), Anbar (2015) and Al-Obeid (2019).

Top of Form

Responses to the items were measured on a 5-point Liket scale: I strongly agree (5), I agree (4), neutral (3), I do not agree (2), I never agree (1). The degree of appreciation of each item was determined according to the arithmetic means, by subtracting the maximum minimum equal to (4), and then dividing the difference by (5) the length of the category (o.80) The means for performance were categorized as follows: 1-1.80 represented a very low grade; $1.81-2.60$ a low grade; $2.61-3.40$ an average grade; 3.41-4.20 a high grade; and 4.21-5 a very high grade.

\subsection{Research methodology reliability:}

To verify the reliability of the questionnaire, it was presented in its initial form to a group of 20 faculty members as arbitrators, in order to take advantage of their observations on the appropriateness, clarity and suitability of the phrases, the accuracy of the language and the possibility 
of adding or deleting items they deemed appropriate. Based on their observations, some modifications were made to the final form.

\subsection{Research stability}

To ensure the stability of the study methods, the internal consistency of the items in the two scales was assessed by Cronbach's Alpha, as shown in Table 2.

Table 2: Internal reliability of the questionnaire (Cronbach's Alpha)

\begin{tabular}{|l|c|}
\hline \multicolumn{1}{|c|}{ Variable } & Stability coefficient (Cronbach's Alpha) \\
\hline Accountability & 0.77 \\
\hline Transparency & 0.72 \\
\hline Independence & 0.82 \\
\hline Participation & 0.86 \\
\hline Ability to solve administrative problems & 0.86 \\
\hline
\end{tabular}

\subsection{Research proceedings}

To achieve the objectives of the study, the following procedures were followed:

- Obtaining an official letter to facilitate the task of the researchers in applying the study tool.

- Preparing the study tool, checking reliability and stability.

- Identifying the study population by referencing the official records of the Ministry of Higher Learning and Scientific Research, obtaining the official numbers of that study, and determining the number of the study sample, (330 faculty members) in a random manner.

- The questionnaire was distributed to the participants; the method of completing the study tool was clarified, and they were assured that their responses would be used only for scientific research purposes.

- Collecting the questionnaires and checking they the data was valid for statistical analysis purposes, and for classification by the study variables.

- Statistically processing, analyzing and interpreting the data using the Statistical Package for the Social Sciences (SPSS), discussing the findings, and making recommendations.

\section{Research Findings}

Question 1: How well do the heads of departments apply the principles of good governance?

- To answer this question, the researchers extracted arithmetic means and standard deviations to determine the order of the principles of good governance according to the responses from the faculty members; see Table 3 .

Table 3: Arithmetic means and standard deviations in descending order

\begin{tabular}{|c|l|c|c|c|l|}
\hline Number & Principles & arithmetic mean & standard deviation & Order & Degree of appreciation \\
\hline $\mathbf{1}$ & Accountability & 4.18 & 0.85 & $\mathbf{1}$ & High \\
\hline $\mathbf{2}$ & Transparency & 3.88 & 0.88 & $\mathbf{2}$ & High \\
\hline $\mathbf{3}$ & Participation & 3.86 & 0.87 & 3 & High \\
\hline $\mathbf{4}$ & Independence & 3.52 & 0.91 & 4 & Medium \\
\hline \multicolumn{2}{|l|}{ Total } & 3.79 & 0.63 & & High \\
\hline
\end{tabular}

Question 2: Are there statistically significant differences at the level of significance $(\alpha=0.05)$ in the good governance of the heads of department by gender and years of experience, from the point of 
view of teachers?

To answer this question, arithmetic means and standard deviations were calculated with the use of one-way analysis of variance (ANOVA) and the T-test to calculate the degree to which the heads of departments apply the principles of good governance, according to each variable of the study. The results for gender are presented in Table 4, and for years of eperience in Table 5.

Table 4: Arithmetic means and T-test results by gender

\begin{tabular}{|c|c|c|c|c|c|c|}
\hline principle & $\begin{array}{c}\text { Gender } \\
\text { variable }\end{array}$ & Number & $\begin{array}{c}\text { arithmetic } \\
\text { mean }\end{array}$ & $\begin{array}{l}\text { standard } \\
\text { deviation }\end{array}$ & $\begin{array}{c}T \\
\text { value }\end{array}$ & $\begin{array}{c}\text { Level of } \\
\text { significance }\end{array}$ \\
\hline \multirow[t]{2}{*}{ Accountability } & Male & 220 & 2.67 & 1.11 & \multirow{2}{*}{0.203} & \multirow{2}{*}{0.839} \\
\hline & Female & 110 & 2.69 & 1.11 & & \\
\hline \multirow[t]{2}{*}{ Transparency } & Male & 220 & 3.53 & 0.92 & \multirow{2}{*}{0.150} & \multirow{2}{*}{0.881} \\
\hline & Female & 110 & $3 \cdot 51$ & 0.94 & & \\
\hline \multirow[t]{2}{*}{ Independence } & Male & 220 & 3.85 & 0.90 & \multirow{2}{*}{0.432} & \multirow{2}{*}{0.666} \\
\hline & Female & 110 & 3.91 & 0.96 & & \\
\hline \multirow[t]{2}{*}{ Participation } & Male & 220 & 4.20 & 0.93 & \multirow{2}{*}{0.793} & \multirow{2}{*}{0.793} \\
\hline & Female & 110 & 4.16 & 1.01 & & \\
\hline \multirow[t]{2}{*}{ Total } & Male & 220 & 3.46 & 0.90 & \multirow{2}{*}{0.943} & \multirow{2}{*}{0.416} \\
\hline & female & 110 & 3.79 & 0.92 & & \\
\hline
\end{tabular}

Table 5: Arithmetic means and ANOVA results according to years of experience

\begin{tabular}{|c|c|c|c|c|c|c|}
\hline principle & $\begin{array}{l}\text { Variable years } \\
\text { of experience }\end{array}$ & number & $\begin{array}{c}\text { Arithmetic } \\
\text { mean }\end{array}$ & $\begin{array}{l}\text { Standard } \\
\text { deviation }\end{array}$ & $\begin{array}{c}\mathrm{F} \\
\text { value }\end{array}$ & $\begin{array}{c}\text { Level of } \\
\text { significance }\end{array}$ \\
\hline \multirow[t]{3}{*}{ Accountability } & Less than 10 years & 107 & 3.77 & 0.93 & \multirow{3}{*}{1.037} & \multirow{3}{*}{0.356} \\
\hline & $10-20$ years & 125 & 2.51 & 1.11 & & \\
\hline & $\begin{array}{l}\text { More than } 20 \\
\text { years }\end{array}$ & 98 & 2.77 & 1.23 & & \\
\hline \multirow[t]{3}{*}{ Transparency } & Less than 10 years & 107 & 3.42 & 0.89 & \multirow{3}{*}{2.851} & \multirow{3}{*}{0.060} \\
\hline & $10-20$ years & 125 & 3.68 & 0.98 & & \\
\hline & $\begin{array}{l}\text { More than } 20 \\
\text { years }\end{array}$ & 98 & 3.38 & 1.11 & & \\
\hline \multirow[t]{3}{*}{ Independence } & Less than 10 years & 107 & 3.83 & 0.94 & \multirow{3}{*}{4.017} & \multirow{3}{*}{0.019} \\
\hline & $10-20$ years & 125 & 4.05 & 0.72 & & \\
\hline & $\begin{array}{l}\text { More than } 20 \\
\text { years }\end{array}$ & 98 & 3.66 & 1.14 & & \\
\hline \multirow[t]{3}{*}{ Participation } & Less than 10 years & 107 & 4.15 & 0.99 & \multirow{3}{*}{4.095} & \multirow{3}{*}{0.018} \\
\hline & $10-20$ years & 125 & 4.36 & 0.74 & & \\
\hline & \begin{tabular}{|l|} 
More than 20 \\
years
\end{tabular} & 98 & 3.94 & 1.21 & & \\
\hline \multirow[t]{3}{*}{ Total } & Less than 10 years & 107 & 3.37 & 0.85 & \multirow[b]{3}{*}{2.452} & \multirow{3}{*}{0.088} \\
\hline & $10-20$ years & 125 & 3.61 & 0.78 & & \\
\hline & $\begin{array}{l}\text { More than } 20 \\
\text { years }\end{array}$ & 98 & 3.34 & 1.96 & & \\
\hline
\end{tabular}

Question 3: What is the level of ability to solve administrative problems among the heads of academic departments from the point of view of the faculty members?

The arithmetic means and standard deviations are shown in Table 6. 
Table 6: Arithmetic means and standard deviations for the level of ability to solve administrative problems

\begin{tabular}{|l|c|c|c|}
\hline Variables & $\begin{array}{c}\text { Arithmetic } \\
\text { mean }\end{array}$ & $\begin{array}{c}\text { standard } \\
\text { deviation }\end{array}$ & $\begin{array}{c}\text { Level of } \\
\text { performance }\end{array}$ \\
\hline $\begin{array}{l}\text { Level of ability to solve administrative problems } \\
\text { among heads of academic departments. }\end{array}$ & 3.78 & 0.76 & High \\
\hline
\end{tabular}

Question 4: Are there statistically significant differences at the level of indication $(\alpha=0.05)$ in the level of ability to solve administrative problems among the heads of academic departments by gender or years of experience?

The findings by gender are presented in Table 7, and by years of experience in Tables $8 \mathrm{a}$ and $8 \mathrm{~b}$ (ANOVA).

Table 7: Arithmetic means and standard deviations, and T-test results for the level of ability to solve administrative problems according to gender

\begin{tabular}{|l|l|c|c|c|c|c|c|}
\hline variable & category & number & $\begin{array}{c}\text { Arithmetic } \\
\text { mean }\end{array}$ & $\begin{array}{c}\text { standard } \\
\text { deviation }\end{array}$ & $\begin{array}{c}\text { Degree of } \\
\text { freedom }\end{array}$ & $\begin{array}{c}\text { T } \\
\text { value }\end{array}$ & $\begin{array}{c}\text { Level of } \\
\text { significance }\end{array}$ \\
\hline \multirow{2}{*}{ Gender } & Male & 220 & 3.80 & 0.78 & \multirow{2}{*}{328} & 0.534 & 0.59 \\
\cline { 2 - 8 } & Female & 110 & 3.93 & 0.64 & 328 \\
\hline
\end{tabular}

Table 8a: Arithmetic means and standard deviations for the level of ability to solve administrative problems according to the years of experience

\begin{tabular}{|l|l|c|c|c|}
\hline variable & Variable levels & Number & Arithmetic means & Standard deviation \\
\hline Years of experience & Less than 10 years & 107 & 3.37 & 0.75 \\
\cline { 2 - 5 } & 10-20 years & 125 & 3.50 & 0.74 \\
\cline { 2 - 5 } & More than 20 years & 98 & 3.29 & 0.79 \\
\cline { 2 - 5 } & Total & 330 & 3.38 & 0.76 \\
\hline
\end{tabular}

Table 8b: ANOVA results for the level of ability to solve administrative problems according to years of experience

\begin{tabular}{|l|l|l|l|l|l|}
\hline Source of variance & Sum of squares & Degree of freedom & Squares mean & F value & Level of significance \\
\hline Between groups & 1.376 & 2 & 0.688 & 0.196 & 0.30 \\
\hline Within groups & 113.330 & 327 & 0.575 & & \\
\hline Total & 114.706 & 329 & & & \\
\hline
\end{tabular}

Question 5: Is there a relationship between the degree of application of the principles of good governance and the level of ability to solve administrative problems among the heads of academic departments?

To answer this question, the coefficient of correlation between the degree of good governance and the level of ability to solve administrative problems was calculated; see Table 9.

Table 9: Pearson correlation coefficient between the degree of good governance and the ability to solve administrative problems

\begin{tabular}{|l|l|c|}
\hline & \multicolumn{2}{|l|}{ Level of ability to solve administrative problems } \\
\hline \multirow{2}{*}{ Good governance practice } & Pearson correlation coefficient & 0.722 \\
\cline { 2 - 3 } & Level of significance & 0.01 \\
\hline
\end{tabular}

The level of statistical significance at the level of significance $(\alpha \geq 0.05)$. 


\section{Discussion}

The results in Table 3 show that the degree of application among the heads of academic departments in the Faculties of Educational Sciences in Jordanian universities to the principles of good governance from the point of view of the faculty members was high. This indicates satisfaction from the faculty members with the extent to which the principles of good governance (accountability, transparency, participation, and independence) are applied by the heads of the academic departments. This suggests that the heads of department are encouraging employees to use the electronic systems in the processes of teaching and learning, motivated by their belief in the importance of technology and its necessity in the educational process. The heads also follow up the outcomes of the educational process by accounting to the faculty, dealing with them equally without distinction or discrimination. The heads of department also favor the independence of faculty members in the implementation of the teaching plans that followed in the department. They seek the participation of all faculty members in decision making and implementation of these decisions, and the participation of nonfaculty members in some decisions, especially graduate students. All of this was reflected in the satisfaction of the faculty members with the heads of departments' application of the principles of good governance, which judged as high. Al-Fara (2013) pointed out that the concept of governance is linked to decision making through the rules, standards and discipline that determine the administration of the organization. Al-Hanini (2004) also confirmed that governance aims to achieve harmony and justice in all administrative processes within the institution, protecting the material and moral rights of individuals and providing the necessary information about the activities of the institution accurately and quickly.

Our finding supports the results of various studies (Mortensen, 2009; Mok, 2016; Nasser al-Din, 2012; Muslim, 2016; Moumni and Ibrahim, 2017; and Najm, 2017) which stated that the level of application of governance was high. However, other studies disagree with ours, finding the application of governance to be only moderate (Al-Arini, 2014; Abu Debel, 2015; Al-Asiri, 2017; Dahdar, 2017; Al-Hamidi, 2017; and Al-Sarhan and Khazaela, 2020).

The results shown in Table 4 indicate no statistically significant differences attributable to gender. This agrees with the findings of Okasha, Ashour and Jourana (2017), but not those of AlAssari (2017).

The results in Table 5 also indicated no statistically significant differences in the degree to which the principles of good governance were applied according to years of experience, which indicates that colleagues seek to apply innovative educational techniques. Al-Taweel (2006) pointed out that university education departments are working to introduce developments and changes that help colleagues in all fields to carry out thorough and continuous reviews of their behaviors and relations with national, regional and international bodies, in order to achieve quality and effectiveness in the teaching and learning process. This agrees with the results of Nasser al-Din (2012) and Okasha, Ashour and Jourana (2017).

Table 5 also shows that the level of departmental heads' ability to solve administrative problems was high. This finding can be explained by the fact that department heads have the own skills tin performing their duties; Amaira (2015) indicated that the personality of the leader is an important element of leadership, because his qualities and personal characteristics have a great impact in determining the directions and responses of employees. Since personality affects the solvency of work, both individually and collectively, in its various manifestations it affects others and their responses. Al-Sudairi (2015) pointed out that a leader's possession of administrative skills plays an important role in his ability to think ahead in the work as well as to be happy in his relationship with the department and his awareness of the impact of change. Also, the possession of technical skills helps the leader to implement what is required of him and achieve the goals of the institution to which he belongs. Hariri (2008) confirmed that the leader has the ability to take responsibility, with a deep and comprehensive understanding of the tasks required of him, and his belief in the goal and the possibility of achieving it is a motive for his success in the department. 
The results of this study coincided with those of Abu Odeh (2004), Ruweished (2004), Abu Aisha (2007), Nazzal (2009) and Al-Obeid (2019), which indicated that the level of ability to solve the problems faced by leaders in their various institutions was high.

The results in Table 6 also shows no statistically significant differences by gender in the responses of the participants to the heads of departments' level of ability to solve administrative problems; that is, by the gender of the participants or of the departmental heads. Our result was in agreement with that of Al-Obeid (2019), but differed from those Glimps (1999) and Abu Odeh (2004).

Table 8 shows no statistically significant differences in the responses of the study sample members about the level of ability to solve administrative problems according to the of years of experience of the heads from the point of view of the faculty members. This lack of statistically significant differences as a whole may be attributed to the years of experience in the sense that faculty members with different lengths of experience agreed to describe the level of ability to solve administrative problems and determine the level of that ability. Our result was consistent with those of Abu Aisha (2007) and Al-Obeid (2019), but contradicted those of Abyat (2004) and Nazzal (2009).

Table 9 shows a strong positive and statistically functioning relationship between the degree of application of the principles of good governance and the level of ability to solve administrative problems among the heads of departments. This can be explained by the fact that the better government is adopted, the better are faculty members able to solve the administrative problems they face, to make policies and decisions about work, and to adopt new methods of management. They develop institutional building based on transparency and accountability, all of which means that heads of department are able to solve administrative problems, from the point of view of faculty members.

\section{Conclusions}

According to the findings observed in the research, we can offer the following conclusions. First, we should incorporate the principles of good governance in courses offered to new faculty members. Second, decision makers should hold workshops and refresher courses in the field of good governance and its principles and involving all faculty members. Third, they should issue regulations and legislation on the standards and principles of good governance in universities and obliging departments and councils within the college to work with them. And finally, they should increase the knowledge of faculty members in the laws and regulations and providing appropriate mechanisms to disseminate that knowledge among faculty members in the departments.

\section{References}

Abdul Wahab, A. (2003). Organizational Behavior, Cairo, Al Wafa Publishing and Distribution House

Abidin, M. (2001). Modern School Administration, I1, Al Shorouk Publishing and Distribution House, Amman, Jordan. Abu Aisha, G. (2007). Educational Planning for Principals of Public Secondary Schools in Palestine, Unpublished Master's Thesis, Najah National University, Nablus, Palestine.

Abu Ayed, M. (2006). Recent Trends in Active Educational Leadership, I1, Al Amal Publishing and Distribution House, Irbid, Jordan.

Abu Debeil, T. (2015). Degree of good governance in the administration of village education from the point of view of administrative staff, unpublished master's thesis, Yarmouk University, Irbid, Jordan.

Abu Nasser, F. (2008). Introduction to Educational Department of Theories and Skills, il Dar al-Marcha, Amman, Jordan.

Abu Odeh, F (2004). Problems and Difficulties facing the Director of the Secondary School in the Gaza Strip, An Unpublished Doctoral Thesis, Graduate Program joint of the Faculty of Education, Ain Shams University, Faculty of Educational Sciences, Al-Aqsa University, Palestine.

Ahmed, S. (2011). Center for Control and Problem-Solving and Relationship in light of some of the variables in some high school students in Abu Sinan village, unpublished master's thesis, Graduate School of Educational and Psychological Studies, Amman University. 
Akasha, I., Ashour, M. \& Jawarana, T. (2019). The degree of application of Arab school principals within the Green Line of administrative governance principles, The Journal of the Islamic University for Educational and Psychological Studies, Volume 27, No. 1, p. 730-750.

Al-Arini, M. (2014). The reality of the application of governance from the point of view of the members of the administrative and academic bodies working at Imam Mohammed Bin Saud Islamic University, International Journal of Education, Specialized, 3(12), 114-148.

Al-Dahdar, M. (2017). Reality of Palestinian University Governance, Islamic University of Economic and Administrative Studies, 25 (1), 62-88.

Al-Farra, M. (2013). The concept of governance and ways to apply it in higher education institutions, The Journal of the Islamic University for Educational and Psychological Studies, Islamic University, Gaza, Palestine.

Al-Ghasali, T. \& Amrain S. (2008). Social Responsibility and Business Ethics, Amman, Wael Publishing House.

Al-Hamidi, M. (2017). The reality of the application of good governance and its constraints at Taif University from the point of view of the members of the academic body, the Journal of the Faculty of Education, Binha University, 28 (110) 155-210.

Al-Hanini, I. (2004). Developing the corporate governance system in public joint stock companies to enhance the independence of the legal auditor, unpublished Doctoral thesis, Amman Arab University for Graduate Studies, Amman, Jordan.

Al-Harbi, Q. (2008). Modern Educational Leadership, I1, Janadriyah Publishing and Distribution, Amman, Jordan.

Al-Lahwani, H. (2007). The problems faced by THE UNRWA school principals for the basic stage from the point of view of school principals and teachers in the governorates of northern Palestine, an unpublished master's thesis, Al-Najah National University, Nablus.

Al-Miliji, R. (2011). Towards a distinguished education in the 21st century: visions of the future and reform entrances, Cairo, Arab Thought House.

Al-Obaid, A. (2019). Degree of positional leadership practice and its relationship to the level of ability to solve administrative problems in the principals of secondary schools in Zarqa governorate from the point of view of teachers, unpublished master's thesis, Hashemite University, Zarqa, Jordan.

Al-Rawili, M. (2019) Academic Leaders Practice degree at King Abdulaziz University of Good Governance from the point of view of faculty members, Jordanian Society of Educational Sciences, Jordanian Educational Journal, Volume 4, Third Issue, p. 238-255.

Al-Ruwaili, M. (2012). Perceptions of private school teachers for the exercise of their principals' leadership role using positional theory in al-Qurayat governorate, Magazine of the Faculty of Education in Mansoura, Issue 81.

Al-Salami, A. (2002). Evolution of Organizational Thought, I2, Gharib Library, Cairo, Egypt.

Al-Sarhan, H. \& Al-Khuza'ala, M. (2020). Level of institutional governance practice at the Faculty of Education at the Hashemite University from the point of view of its faculty members, Sharjah University of Humanities and Social Sciences Magazine Volume 17, Issue 2, 169-194.

Al-Shafei, H. (2009). Governance in Physical and Sports Education, Alexandria, Al Wafa Publishing, Printing and Publishing House, Egypt.

Al-Sudairi, M. (2015). The competence of cognitive representation and its relationship to the skill of problemsolving among the students of Qassim University, an unpublished Doctoral thesis, Faculty of Education, Qassim University.

Al-Taweel, H. (2006). Educational Administration and Organizational Behaviorm2.Ammanm Dar Wael.

Anbar, A. (2015). Working Memory and Motivation and Their Relationship to the Effective Problem-Solving of University Students, Unpublished PhD, 2015, Faculty of Education, Yarmouk University, Jordan.

Aqelan, K. (2011). Administrative Problems in Basic Education Schools in The Hashemite Kingdom of Jordan: Field Study, Unpublished Master's Thesis, Al-Azhar University, Egypt

Aqelan, K. (2011). Administrative Problems in Basic Education Schools in The Hashemite Kingdom of Jordan: Field Study, Unpublished Master's Thesis, Al-Azhar University, Egypt.

Asiri, K. (2017). The reality of the governance of Prince Saltam Bin Abdulaziz University in light of Saudi Arabia's Vision 2030 from the point of view of its administrative and academic leaders, an unpublished master's thesis, Prince Sultan University of Saudi Arabia.

Bani. J., Joudat, S. \& Al-Maaita, A. (2002). Entrance to Psychology, I1, Cultural Publishing and Distribution House, Amman, Jordan.

Dahawi, B. \& Al-Maliji, R. (2011). Comparative Study of The Institutional Governance Systems of Universities in South Africa and Zimbabwe, a paper presented to the 19th Annual Education and Human Development Conference in the Countries of Africa organized by the Egyptian Society for Comparative Education, Cairo, And a in-Shams University. 
Dahshan, H. (2018). Degree of application of the heads of academic departments in private universities to the principles of governance and its relation to the degree of availability of their organizational culture, unpublished master's degree, Middle East University, Amman, Jordan

Effendi, A. (2004) Extended Governance Framework of The Conference on Trends in The Management of Civil Society Institutions, Cairo.

Glimps, J., (1999). Comparisons of Problem Solving Processes of Education Administration leadership, Gender Decision Making University of Texas, Dissertation Abstracts International, 5901(1) p.35.

Groan, F. (2007). Thinking Education, Concepts and Applications, Think House for Publishing and Distribution, Amman, Jordan.

Hamadat, M. (2017). Educational Department, Contemporary Jobs and Issues, Al-Hamid Publishing and Distribution House, Amman, Jordan. Damascus.

Hariri, R. (2008). Educational leadership skills in administrative decision-making, I1, Dar al-Curriculum for Publishing and Distribution, Amman, Jordan.

Higgins. M.J., (2001). Creative Problems solving Techniques, The Hand book of New ideas for Business, New Management Publishing Company Inc. New York

Hilal, M. (2003). Decision-Making Skills, I1, Center for Performance Development and Development, Cairo, Egypt.

Imran, M. (2014). Habits of reason and its relationship to problem solving strategy - a comparative study of outstanding and ordinary students, Master's thesis, Faculty of Education, Al-Azhar University, Egypt

Justice, A. \& Abdul Wahab, S. (2003). Ability to solve problems and skills beyond the knowledge of ordinary and mentally superior, Journal of the Faculty of Education (Education and Psychology), 27 (3) p. 1818-258.

Khurshid, M. (2008). challenges reality and visions of the future the role of students and legislative reform in the administration of the University, a workshop organized by the Arab Reform Forum at the Library of Alexandria.

Mehdi, I. \& Al-Qaisin A. (2017). The concept of governance among the heads of scientific departments at The University of Baghdad and its teaching, International Conference on Governance in International Educational Institutions, University Governance Council for March 11-13, Middle East University, Amman, Jordan.

Mehdi, I. (2017). The concept of governance at the heads of scientific departments at The University of Baghdad and its teaching, International Conference on Governance in International Educational Institutions, University Governance Council for March 11-13, Middle East University, Amman, Jordan.

Moumni, (2019). the degree of application of good governance in the directorates of education in northern Jordan and its relationship to the effectiveness of administrative performance from the point of view of its administrative staff. Journal of the Islamic University of Educational and Psychological Studies, Volume 27, No. 1, p. 589-616.

Muslim, B. (2016). Degree of Governance Practice at the University of Science and Technology from the point of view of academic and administrative leaders, unpublished master's thesis, University of Science and Technology, Amman, Jordan.

Najm, N. (2017). Degree of practice of governance principles at the University College of Applied Sciences in Gaza from the point of view of workers and ways to develop it, an unpublished master's thesis, Islamic University, Gaza.

Nasser al-Din, Y. (2012). The reality of the application of governance at the Middle East University from the point of view of its faculty and management staff, Middle East University, Amman, Jordan.

Nazzal, M. (2009). The relationship between the degree of practice of educational decisions and the degree of ability to solve problems among the principals of public secondary schools in the governorates of the northern West Bank from the point of view of the principals and principals themselves, an unpublished master's thesis, Al-Najah University, Nablus, Palestine.

Obeidat, H. (2004). Administrative Problems Facing Teachers of Physical Education at Balqa Applied University, Unpublished Master's Thesis, Yarmouk University, Irbid, Jordan.

Ruishid, F. (2004). Administrative Problems Facing TeacherS Colleges in the Northern Region of Saudi Arabia and Proposed Solutions, Unpublished Master's Thesis, Yarmouk University, Irbid, Jordan.

Samara, N. \& al-Adly, A. (2007). Concepts and Terminology in Educational Sciences, I1, Dar al-Marcha, Amman, Jordan.

Zaghloul, R. \& Al-Zaghloul, E. (2003). Cognitive Psychology, I1, Al-Sharq Publishing and Distribution House, Amman, Jordan. 